\title{
Container maritime transport on an international scale: data envelopment analysis for transhipment port
}

\author{
F. Russo \& C. Rindone \\ Università degli Studi Mediterranea di Reggio Calabria, \\ DIMET - Dipartimento di Informatica, Matematica, \\ Elettronica e Trasporti, Italy
}

\begin{abstract}
Port's performances depend on infrastructural and service characteristics. It is possible to adopt different evaluation methods to compare these performances. In this work a state of the art evaluation method to compare container ports is reported. Non-parametric methods are analysed and in particular applications of Data Envelopment Analysis (DEA) are reported. Prototypal results of DEA application for a set of Mediterranean container ports are presented.
\end{abstract}

Keywords: transhipment port, evaluation methods, DEA.

\section{Introduction}

Port characteristics and their possible evolutions are defined in relation to specific transportation planning dimensions $[1,2]$. Respect to temporal dimension, three main commercial functions of a port can be defined: regional port, gateway, transhipment. Regional port competition regards only ports with similar external conditions. Gateway port competition regards ports with connection availability to high level of service quality railways and highways. Transhipment port competition regards ports with a hub and spoke function at intercontinental scale. Then for regional and gateway ports the competition is driven by external elements and the internal elements that define the specific port are sometime not important. The most important competition regards transhipment ports. Infrastructures and services influence competition between hub ports even if also non-material characteristics influence the challenge but in this case the weight is lower. 
Infrastructural characteristics influence port choice and often it constitutes constraints for some typologies of maritime traffic: for instance, quay depth influences transhipment traffic. Services characteristics supplied in a port, given the same infrastructural characteristics, are decisive factors in maritime travel choices.

At strategic scale evaluation concerns infrastructures investments, while at tactical scale, infrastructural characteristics can be considered constant, and then evaluation concerns principally services.

Investments evaluation is finalised to compare effects produced after implementation of infrastructures and services. Comparisons are carried out respect to one or more factors. The method generally adopted to evaluate infrastructural investments is Cost Benefit Analysis (CBA). One of limits of CBA concerns in the difficulty to consider non monetary effects. To overcome this limit, multicriteria methods can be adopted. These methods allow the comparison of effects that in some cases can be incommensurable. Most multicriteria methods require some information on preference of decision makers that are generally represented through weights. Specification of weight influences strongly results $[3,4]$ and in some case multicriteria is equivalent to CBA.

A different approach can be used for services. Services are modelled as a productive process characterised by a set of inputs that are combined to obtain a set of outputs. Investments, represented by means of a productive process are compared in terms of efficiency that is the capacity to transform a set of inputs into a set of outputs.

A possible method to analyse competition among ports is performance measurement that assume a relevant role in analysis of current situation and to support decision maker for possible future scenarios $[5,6]$.

A productive process is represented by means of a production function that is the relationship between quantity of inputs used and quantity of product resulting. A production frontier function is an extension of production function and it represents ideally maximum output obtainable with a given set of inputs [7].

Different methods to estimate efficiency are available in literature. A classification of these methods comprehends:

- parametric methods, based on the assumption that the production function of fully efficient firms is known [8]; a method is Stochastic Frontier Analysis (SFA) [9];

- non-parametric methods, based on the assumption that the production function of fully efficient firms is not known; some methods are Data Envelopment Analysis (DEA) [10] and Free Disposal Hull (FDH) [11, 12].

In this paper a DEA non-parametric method is proposed to evaluate in the same time infrastructures and services in a transhipment port. DEA was originally introduced to evaluate production efficiency in industrial systems, where inputs are labour, energy and capital resources and outputs are goods or services. Starting from Farrell's definition of efficiency [13], the first formulation of DEA was introduced by Charnes et al. [10], it was indicated with 
the acronym CCR referring to author's names. This formulation was based on the hypothesis of Constant Returns to Scale (CRS). An extension of the CCR model, denoted with the acronym BCC, has been proposed by Banker et al. [14], in which the CRS hypothesis is removed and Variable Returns to Scale (VRS) (decreasing or increasing) are admitted.

DEA is based on technical efficiency concept that measures capacity of a decision unit (or in general Decision Making Unit - DMU) to realize a productive process that combines production factors (input) to obtain a product (output). Then, each DMU is represented by means of a set of one, or more, inputs and a set of one, or more, outputs.

Defining the space of input variables $\left(\mathrm{R}^{\mathrm{r}}\right)$ and output variables $\left(\mathrm{R}^{\mathrm{s}}\right)$, each DMU can be allocated in a point representative of his efficiency belonging to the space $\mathrm{R}^{(\mathrm{r} \cup \mathrm{s})}$.

Efficient DMUs belong to the frontier. The distance from this frontier is a measure of inefficiency of a DMU, that could be eliminated through a variation in quantity of inputs (input-oriented) or outputs (output-oriented) or both (additive model) [15]. Time variation of efficiency measures is considered according to different approaches. Common approaches presented in literature are: contemporaneous approach; intertemporal approach; sequential approach; windows analysis [16, 17]. These approaches differ on construction of observation set into different temporal periods.

DEA has subsequently been applied in many fields of economics and engineering [18]. The main works on transport planning regard evaluation performance of: urban transport systems [19, 20], air transport systems [21], transport system in emergency conditions [22, 23], railways systems [24, 25]. The general works regard the support decision making process in the phases of selection and ranking of alternative scenarios [26-29].

In this paper we propose to use the DEA approach to analyse the comparative effectiveness on a set of hub ports.

Each port is represented by means of a virtual productive process fed by a set of inputs that generate a set of outputs. Inputs comprehend a set of resources needed to realise infrastructures and/or services to perform functions of a transhipment port. Outputs of process comprehend two different time levels: the first level, defined properly output, comprehends products and services immediately available after investments (for instance a new higher depth quay or the cranes availability); the second level, defined outcome, comprehends effects produced by the terminal using infrastructures and services for instance annual container throughput in a port using depth quay and cranes. Starting from a set of alternative investments that can be made, DEA can be applied to compare investments represented in terms of inputs and the time level of results, output and outcome. It is possible to distinguish efficient and not efficient alternatives considering supply modification and effectiveness considering demand interception.

The paper is organized as follows. In section 2 DEA non-parametric methods are recalled, with a survey on the applications for maritime transport. In section 3 prototypal results of a DEA application for a set of container ports in 
Mediterranean context are presented. In section 4 some final considerations are reported.

\section{DEA in transportation planning}

\subsection{Definitions and notations}

A transportation system is represented by means of a productive process characterised from a set of inputs that generates a set of outputs, adopting to DEA approach.

The analytic formulation of DEA is based on an efficiency measure $\left(\theta_{j}\right)$ of $j^{\text {th }}$ process in terms of ratio between output $\left(\mathrm{O}_{\mathrm{j}}\right)$ and input $\left(\mathrm{I}_{\mathrm{j}}\right)$ :

$\theta_{\mathrm{j}}=\mathrm{O}_{\mathrm{j}} / \mathrm{I}_{\mathrm{j}}$

$(j=1, \ldots, n)$

The CCR form of efficiency measurement problem can be written as a set of $\mathrm{n}$ linear programming problems to obtain unknown weights assigned to inputs and outputs. If the goal is pursued for increasing values of output, it follows that objective function has to be maximized; otherwise, objective function has to be minimized.

In the maximizing form the $\mathrm{j}^{\text {th }}$ problem is expressed:

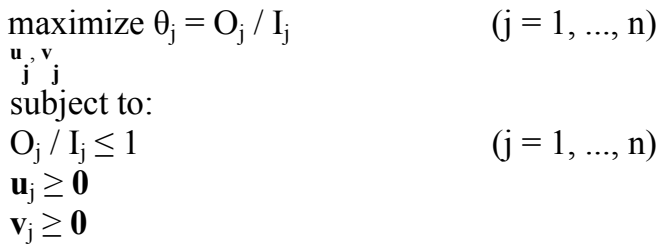

where

$\mathrm{O}_{\mathrm{j}}=\mathbf{u}_{\mathrm{j}}^{\mathrm{T}} \mathbf{o}_{\mathrm{j}}$

$\mathrm{I}_{\mathrm{j}}=\mathbf{v}_{\mathrm{j}}^{\mathrm{T}} \mathbf{i}_{\mathrm{j}}$

$\mathbf{o}_{\mathrm{j}} \in \mathrm{R}^{\mathrm{s}}:\left(\mathrm{o}_{1}, \ldots, \mathrm{o}_{\mathrm{s}}\right)^{\mathrm{T}}$

is the measure of output for $\mathrm{j}^{\text {th }}$ process;

is the measure of input for $\mathrm{j}^{\text {th }}$ process;

$\mathbf{i}_{\mathrm{j}} \in \mathrm{R}^{\mathrm{r}}:\left(\mathrm{i}_{1}, \ldots, \mathrm{i}_{\mathrm{r}}\right)^{\mathrm{T}}$

vector of outputs;

$\mathbf{u}_{\mathrm{j}} \in \mathrm{R}^{\mathrm{s}}:\left(\mathrm{u}_{1}, \ldots, \mathrm{u}_{\mathrm{s}}\right)^{\mathrm{T}}$

vector of inputs;

vector of unknown weights for each

$\mathbf{v}_{\mathrm{j}} \in \mathrm{R}^{\mathrm{r}}:\left(\mathrm{v}_{1}, \ldots, \mathrm{v}_{\mathrm{r}}\right)^{\mathrm{T}}$ component of outputs;

vector of unknown weights for each component of inputs.

This formulation, for each $\mathrm{j}^{\text {th }}$ process, allows to find the set of weights, $\mathbf{u}_{\mathrm{j}}$ and $\mathbf{v}_{\mathrm{j}}$, that maximize the efficiency indicator, $\theta_{\mathrm{j}}$, assuming that the maximum value is equal to one.

The efficient frontier is obtained from envelopment of points representing efficient planning process. Points not belonging to the frontier represent nonefficient processes. Among the considered processes, there is at least one that is efficient. The distance from the frontier may be calculated for the inefficient points. 


\subsection{DEA for maritime transport system}

In recent years several studies applying DEA, to evaluate efficiency of container ports have been developed in literature. These applications are referred to different set of ports at international scale, European and Mediterranean [30-33].

Input generally are: capital, for instance, in terms of number of quays for containers; labour, for instance, in terms of human resources dedicated to container traffics; port equipments, for instance, in terms of available cranes; land, for instance, in terms of surface dedicated to container terminal.

Outputs generally are: annual container throughput (TEU) or container throughput in a peak work hour; these measures represent indirectly a measure of quantity and quality of supplied services in a port.

Non-parametric methods generally applied are DEA and Free Disposal Hull (FDH). Proposed formulations are CCR, BCC input oriented, output oriented or additive model.

Classification of inputs (capital, labour, equipment and land), generally adopted in the applications of DEA to evaluate port's performances, can result not directly connected to temporal dimensions of transport planning. Using input classification, generally used in literature, a comparison of port performances in different temporal dimensions of transportation planning is complex; especially considering evolution of infrastructures and services characteristics.

A proposed classification referred to transportation planning activities comprehends: activities related to material infrastructure that include interventions to modify physical characteristics of transport system elements; activities related to non-material that include the consolidated research, learning and training, and other activities connected to telematics or Intelligent Transportation System; activities related to equipment that include interventions to provide operative tools that contribute to realise specific services; activities related to management that include interventions to manage transportation system; activities related to governance and institutional that include interventions to regulate transportation system.

Literature concerning DEA applications for container ports is classified according to the following criteria (Tab. 1):

- $\quad$ set of ports for which efficiency is calculated (Set of DMU);

- set of considered activities classified on, material infrastructures, non materials, equipment, management, institutional and governance (the last two are grouped in a only class), (input);

- $\quad$ set of considered output (output);

- DEA specification: Input Oriented (IO), Output Oriented (OO), Additive Model (AM) (specification);

- DEA model CCR, BCC, FDH (typology of model).

\section{DEA for Mediterranean container ports}

In this paper an application of DEA to compare effectiveness of main transhipment container ports in the same area is presented. The application is 
Table 1: Classification of literature concerning DEA applications.

\begin{tabular}{|c|c|c|c|c|c|}
\hline Paper & Set of DMU & Input & Output & Spec.* & $\begin{array}{l}\text { Typ. of } \\
\text { model }\end{array}$ \\
\hline $\begin{array}{l}\text { Tongzon } \\
{[34]}\end{array}$ & $\begin{array}{l}4 \text { australian } \\
\text { container } \\
\text { ports } \\
12 \text { international } \\
\text { container } \\
\text { ports }\end{array}$ & $\begin{array}{l}\text { Material infrastructures } \\
\text { - Terminal area }\left(\mathrm{m}^{2}\right) \\
\text { - Number of container berths } \\
\text { Non-material infrastructures } \\
\text { - Number of stevedores } \\
\text { Management, institutional } \\
\text { and governance } \\
\text { - Delay times } \\
\text { Equipment } \\
\text { - Number of cranes } \\
\text { - Number of tugs }\end{array}$ & $\begin{array}{l}\text { - Container } \\
\text { throughput } \\
\text { (TEU) } \\
\text { - Throughput } \\
\text { (tons) }\end{array}$ & $\mathrm{AM}$ & CCR \\
\hline $\begin{array}{l}\text { Valentine } \\
\text { and } \\
\text { Gray [35] }\end{array}$ & $\begin{array}{l}31 \text { international } \\
\text { container } \\
\text { ports }\end{array}$ & $\begin{array}{l}\text { Material infrastructures } \\
\text { - Total quays length (m) } \\
\text { - Container quay length (m) }\end{array}$ & $\begin{array}{l}\text { - Container } \\
\text { throughput } \\
\text { (TEU) } \\
\text { - Throughput } \\
\text { (tons) } \\
\end{array}$ & & CCR \\
\hline $\begin{array}{l}\text { Cullinane et } \\
\text { al. } \\
{[36]}\end{array}$ & $\begin{array}{l}30 \text { international } \\
\text { container } \\
\text { ports }\end{array}$ & $\begin{array}{l}\text { Material infrastructures } \\
\text { - Terminal area }\left(\mathrm{m}^{2}\right) \\
\text { - Total quays length }(\mathrm{m}) \\
\text { Equipment } \\
\text { - Total number of cranes } \\
\text { - Number of yard gantry } \\
\text { - Number of straddle carriers }\end{array}$ & $\begin{array}{l}\text { - Container } \\
\text { throughput } \\
\text { (TEU) }\end{array}$ & $\mathrm{OO}$ & $\begin{array}{l}\text { CCR } \\
\text { BCC }\end{array}$ \\
\hline $\begin{array}{l}\text { Cullinane et } \\
\text { al. } \\
{[37]}\end{array}$ & $\begin{array}{l}57 \text { terminals of } \\
28 \\
\text { international } \\
\text { container } \\
\text { ports }\end{array}$ & $\begin{array}{l}\text { Material infrastructures } \\
\text { - Terminal area }\left(\mathrm{m}^{2}\right) \\
\text { - Quay length }(\mathrm{m}) \\
\text { Equipment } \\
\text { - Number of cranes } \\
\text { - Number of yard gantry } \\
\text { - Number of straddle carriers }\end{array}$ & $\begin{array}{l}\text { - Container } \\
\text { throughput } \\
\text { (TEU) }\end{array}$ & IO & $\begin{array}{l}\mathrm{CCR} \\
\mathrm{BCC} \\
\mathrm{FDH}\end{array}$ \\
\hline $\begin{array}{l}\text { Cullinane et } \\
\text { al. } \\
{[38]}\end{array}$ & $\begin{array}{l}57 \text { terminals of } \\
28 \\
\text { international } \\
\text { container } \\
\text { ports }\end{array}$ & $\begin{array}{l}\text { Material infrastructures } \\
\text { - Total quays length }(\mathrm{m}) \\
\text { - Terminal surface }\left(\mathrm{m}^{2}\right) \\
\text { Equipment } \\
\text { - Total number of cranes } \\
\text { - Number of yard gantry } \\
\text { - Number of straddle carriers }\end{array}$ & $\begin{array}{l}\text { - Container } \\
\text { throughput } \\
\text { (TEU) }\end{array}$ & $\mathrm{OO}$ & $\begin{array}{l}\text { CCR } \\
\mathrm{BCC}\end{array}$ \\
\hline $\begin{array}{l}\text { de Carvalho } \\
\text { [39] }\end{array}$ & $\begin{array}{l}5 \text { portuguese } \\
\text { multipurpose } \\
\text { ports }\end{array}$ & $\begin{array}{l}\text { Material infrastructures } \\
\text { - Investments expenses } \\
\text { Management, institutional } \\
\text { and governance } \\
\text { - Managerial expenses }\end{array}$ & $\begin{array}{l}\text { - General } \\
\text { cargo (tons) } \\
\text { - Ro-Ro (tons) } \\
\text { - Container } \\
\text { (tons) } \\
\text { - Dry (tons) } \\
\text { - Liquid (tons) } \\
\text { - Number of } \\
\text { passengers } \\
\end{array}$ & IO & $\begin{array}{l}\text { CCR } \\
\text { BCC }\end{array}$ \\
\hline $\begin{array}{l}\text { Al-Eraqi et } \\
\text { al. } \\
{[40]}\end{array}$ & $\begin{array}{l}22 \text { Middle East } \\
\text { and } \\
\text { East Africa } \\
\text { ports }\end{array}$ & $\begin{array}{l}\text { Material infrastructures } \\
\text { - Distance from Hong Kong } \\
\text { (nautical miles) } \\
\text { - Terminal area }\left(\mathrm{m}^{2}\right) \\
\text { - Quay length }(\mathrm{m})\end{array}$ & $\begin{array}{l}\text { - Throughput } \\
\text { (tons) } \\
\text { - Total ships }\end{array}$ & $\begin{array}{l}\mathrm{IO} \\
\mathrm{OO}\end{array}$ & $\begin{array}{l}\text { CCR } \\
\text { BCC }\end{array}$ \\
\hline $\begin{array}{l}\text { Ferrari and } \\
\text { Basta } \\
([41],[42])\end{array}$ & $\begin{array}{l}8 \text { italian } \\
\text { container } \\
\text { ports }\end{array}$ & $\begin{array}{l}\text { Material infrastructures } \\
\text { - Terminal area }\left(\mathrm{m}^{2}\right) \\
\text { - Quay length }(\mathrm{m}) \\
\text { - Quay depth }(\mathrm{m}) \\
\end{array}$ & $\begin{array}{l}\text { - Container } \\
\text { throughput } \\
\text { (TEU) }\end{array}$ & $\mathrm{OO}$ & $\mathrm{BCC}$ \\
\hline
\end{tabular}

\footnotetext{
* AM: Additive Model; IO: Input Oriented; OO: Output Oriented
} 
finalised to obtain frontier efficiency starting from available data relative to the period 2006-2008. We can use the term efficiency but, recalling the specifications before introduced, the current should be effectiveness.

Database is obtained from results of a two-year research project financed by the Italian Ministry of University and Research, whose general objective is to define guidelines for the competitiveness of the Italian transhipment ports of Gioia Tauro, Cagliari and Taranto in the euro-Mediterranean context. Other specific lines of research concern the development, and the application to the Mediterranean area, of aggregate procedures [43] and models [44] to estimate the demand variables of container maritime transport, of choice models of maritime container services and ports [45], of methods to evaluate the efficiency of container transhipment ports. During the project development, a homogeneous database, related to the main container ports in Mediterranean sea, realised. Database collects information about: infrastructural supply that comprehends available infrastructures relative to land and sea sides; services supply for container traffic, in terms of lines and frequencies that reach ports; container transport demand, expressed in terms of throughput in analysed ports (TEU).

In this paper, starting from the full database, that comprehends all ports for which homogeneous information is available, three different port subsets are considered:

- subset of container ports in which annual container throughput is more than $500.000 \mathrm{TEU}$ and less than 1.000.000 TEU and that have, respect to annual container throughput, a transhipment incidence greater than $80 \%$ : Cagliari, Damietta and Taranto (Mediterranean medium transhipment ports);

- subset of container ports in which annual container throughput is more than 1.000.000 TEU and that have, respect to annual container throughput, a transhipment incidence more than 80\%: Algeciras, Gioia Tauro, Marsaxlokk and Port Said (Mediterranean large transhipment ports);

- subset of container ports that have, respect to annual container throughput, a transhipment incidence more than 80\%: Cagliari, Damietta and Taranto, Algeciras, Gioia Tauro, Marsaxlokk and Port Said (Mediterranean transhipment ports).

DEA exercise is applied for each port subset.

In order to represent productive process of each port, the following data are selected:

- two inputs,

- length of quay dedicated to container traffic with depth more than 14 meters (quay length);

- number of cranes dedicated to container traffic (cranes number);

- one output, annual quantity of TEU relative to each port (TEU/year).

DEA methods applied are relative to CCR and BCC formulations; in all cases input oriented specification is adopted.

Results are presented in aggregate form, considering the following classes:

- efficient ports with an index equal to 1 (efficient ports synthetically indicated with "E"); 
- inefficient ports with an index included in the range between 0,9 and 1 (inefficient ports synthetically indicated with the symbol "***");

- $\quad$ inefficient ports with an efficiency index included in the range between 0,6 and 0,9 (inefficient ports synthetically indicated with the symbol "**");

- inefficient ports with an efficiency index included in the range between 0 and 0,6 (inefficient ports synthetically indicated with the symbol “*”).

\subsubsection{Mediterranean medium transhipment ports}

Concerning the subset Mediterranean medium transhipment ports (Tab. 2):

- considering a productive process characterised by one input (cranes number) and one output (TEU/year) result that:

- in the CCR case, Algeciras is efficient; other considered ports are inefficient;

- in the BCC case, Algeciras and Cagliari are efficient; other considered ports are inefficient;

- considering a productive process characterised by two input (cranes number and quay length) and one output (TEU/year) result that:

- in the CCR case, Algeciras and East Port Said are efficient; other considered ports are inefficient;

- $\quad$ in the BCC Algeciras, East Port Said, Cagliari and Damietta are efficient; other considered ports are inefficient.

\subsubsection{Mediterranean large transhipment ports}

Concerning the subset Mediterranean large transhipment ports (Tab. 2):

- considering a productive process characterised by one input (cranes number) and one output (TEU/years) result that:

- in the CCR case, the only one efficient port is Cagliari; other considered ports are inefficient;

- in the BCC case, all considered ports are efficient (Cagliari, Damietta and Taranto);

- considering a productive process characterised by two input (cranes number and quay length) and one output (TEU/years) result that:

- in the CCR case, Cagliari and Damietta are efficient; other considered ports are inefficient;

- in the BCC case, all considered ports are efficient (Cagliari, Damietta and Taranto).

\subsubsection{Mediterranean transhipment ports}

Concerning the subset Mediterranean transhipment ports (Tab. 2):

- considering a productive process characterised by one input (cranes number) and one output (TEU/years) result that:

- in the CCR case, the only one efficient port is Algeciras; other considered ports are inefficient;

- $\quad$ in the BCC case, Algeciras, Gioia Tauro and East Port Said are efficient; Marsaxlokk is inefficient; 
- considering a productive process characterised by two input (cranes number and quay length) and one output (TEU/years) result that:

- in the CCR case, Algeciras and East Port Said are efficient; other considered ports are inefficient;

- in the BCC case, Algeciras, Gioia Tauro and East Port Said are efficient; Marsaxlokk is inefficient.

Table 2: $\quad$ Summary of results from DEA applications.

\begin{tabular}{|c|c|c|c|c|c|c|c|c|c|c|c|c|}
\hline \multirow[b]{2}{*}{ Port } & \multicolumn{4}{|c|}{$\begin{array}{l}\text { Mediterranean medium } \\
\text { transhipment ports }\end{array}$} & \multicolumn{4}{|c|}{$\begin{array}{c}\text { Mediterranean large } \\
\text { transhipment ports }\end{array}$} & \multicolumn{4}{|c|}{$\begin{array}{l}\text { Mediterranean } \\
\text { transhipment ports }\end{array}$} \\
\hline & $\begin{array}{l}1 \mathrm{i} 1 \mathrm{o} \\
\mathrm{CCR}\end{array}$ & $\begin{array}{l}1 \mathrm{i} 1 \mathrm{i} \\
\mathrm{BCC}\end{array}$ & $\begin{array}{l}2 \mathrm{i} 1 \mathrm{lo} \\
\mathrm{CCR}\end{array}$ & $\begin{array}{l}2 \mathrm{i} 1 \mathrm{lo} \\
\mathrm{BCC}\end{array}$ & $\begin{array}{l}\text { 1i } 10 \\
\text { CCR }\end{array}$ & $\begin{array}{l}1 \mathrm{i} 1 \mathrm{lo} \\
\mathrm{BCC}\end{array}$ & $\begin{array}{l}2 \mathrm{i} 1 \mathrm{i} \\
\mathrm{CCR}\end{array}$ & $\begin{array}{l}2 \mathrm{i} 1 \mathrm{o} \\
\mathrm{BCC}\end{array}$ & $\begin{array}{l}\text { 1i_1o } \\
\text { CCR }\end{array}$ & $\begin{array}{l}1 \mathrm{i} \_10 \\
\mathrm{BCC}\end{array}$ & $\begin{array}{l}2 \mathrm{i} 1 \mathrm{o} \\
\mathrm{CCR}\end{array}$ & $\begin{array}{l}2 \mathrm{i} 1 \mathrm{l} \\
\mathrm{BCC}\end{array}$ \\
\hline Cagliari & $\mathrm{E}$ & $\mathrm{E}$ & $\mathrm{E}$ & $\mathrm{E}$ & & & & & $* *$ & $\mathrm{E}$ & $* *$ & $\mathrm{E}$ \\
\hline Damietta & $* *$ & E & E & E & & & & & $*$ & $* *$ & $* *$ & E \\
\hline Taranto & $*$ & E & $* *$ & E & & & & & $*$ & $*$ & $*$ & $* *$ \\
\hline Algeciras & & & & & $\mathrm{E}$ & $\mathrm{E}$ & $\mathrm{E}$ & $\mathrm{E}$ & $\mathrm{E}$ & $\mathrm{E}$ & $\mathrm{E}$ & $\mathrm{E}$ \\
\hline Gioia Tauro & & & & & $* * *$ & $\mathrm{E}$ & $* * *$ & $\mathrm{E}$ & $* * *$ & $* * *$ & $* * *$ & $* * *$ \\
\hline Marsaxlokk & & & & & * & $* * *$ & $*$ & $* * *$ & $*$ & $*$ & $*$ & $* *$ \\
\hline East Port Said & & & & & $* *$ & $\mathrm{E}$ & E & $\mathrm{E}$ & $* *$ & $* *$ & E & E \\
\hline $\begin{array}{ll}1 i_{-10} 1 \mathrm{l} & 1 \text { input } \\
2 \mathrm{i}_{-} 1 \mathrm{o}: & 2 \text { input } \\
\mathrm{E}: & \text { efficien } \\
* * *: & \text { efficien } \\
* *: & \text { efficien } \\
*: & \text { efficien }\end{array}$ & $\begin{array}{l}\text { ranes } \mathrm{n} \\
\text { cranes } 1 \\
\text { ort } \\
\text { index } \\
\text { index } \\
\text { index }\end{array}$ & $\begin{array}{l}\text { Imber), } \\
\text { umber, } \\
\text { nclude } \\
\text { nclude } \\
\text { nclude }\end{array}$ & $\begin{array}{l}1 \text { outpu } \\
\text { quay le } \\
\text { in the } 1 \\
\text { in the } 1 \\
\text { in the } 1\end{array}$ & $\begin{array}{l}\text { ange }[0 \\
\text { ange }[0 \\
\text { ange }[0\end{array}$ & $\begin{array}{l}\text { ar) } \\
\text { tput (1 } \\
1) \\
0,9) \\
6)\end{array}$ & EU/yea & & & & & & \\
\hline
\end{tabular}

\section{Final considerations}

Non-parametric methods measure efficiency of a port respect to a frontier production function that depends on the set of ports considered. This means that if set changes, then measure of efficiency can be different.

Prototypal results of DEA applications presented in this paper show that efficiency of transhipment ports varies with of DEA method, formulation and the subset of considered data. In all DEA specification analysed: considering competition among all and Mediterranean large transhipment ports, Algeciras port results efficient; in the competition among Mediterranean medium transhipment ports, Cagliari results efficient; Marsaxlokk in all set of transhipment ports results inefficient; Egyptian ports (Damietta and East Port Said) and the other Italian ports (Taranto and Gioia Tauro) have high index of efficiency considering BCC specifications. At medium term, activation of Tanger Med port in Morocco could modify relative efficiency of Mediterranean transhipment ports. At strategic scale, activation of Enfidha port in Tunisia could introduce a new element of congestion among Mediterranean ports.

\section{References}

[1] Russo F. \& Rindone C., Dalla pianificazione alla progettazione dei sistemi di trasporto: processi e prodotti, Franco Angeli Editore, Milano, ISBN: 9788846490612, 2007. 
[2] Russo F. \& Rindone C., Safety of users in road evacuation: planning internal processes and guidelines, WIT Transactions on the Built Environment, volume 96, pp. 825-834, 2007.

[3] Russo F. \& Vitetta A., A topological method to choose optimal solutions after solving the multi-criteria urban road network design problem. Transportation. Volume 33, Issue 4, pp. 347-370, 2006.

[4] Russo F. \& Vitetta A., An assignment model with modified Logit, which obviates enumeration and overlapping problems. Transportation. Volume 30, Issue 2, pp. 177-201, 2003.

[5] UNCTAD, Measuring and Evaluating Port Performance and Productivity http://www.unctad.org/en/docs/ship4946_en.pdf (last access February 2009), 1987.

[6] Dyson, R. G., Performance measurement and data envelopment analysis Ranking are rank!, OR Insight, 13(4), pp. 3-8, 2000.

[7] Pesaran H. M. \& Schmidt P., Handbook of Applied Econometrics Volume II: Microeconomics, eISBN: 9780631216339, Blackwell Reference Online ®, Blackwell Publishing Inc., 1999.

[8] Coelli, T., Rao, D. S. P. \& Battese, G., E., An Introduction to Efficiency and Productivity Analysis, Kluwer Academic Publishers, 1998.

[9] Aigner, D., Lovell, K. \& Schmidt, P., Formulation and estimation of stochastic frontier models, Journal of Econometrics 6 (1), pp 21-37, 1977.

[10] Charnes A., Cooper W.W. \& Rhodes E., Measuring the efficiency of decision making units, European Journal of Operational Research 2, pp. 429-444, 1978.

[11] Deprins, D., Simar, L. \& Tulkens, H., Measuring labour efficiency in post offices, In: Marchand, M., Pestieau, P. \& Tulkens, H. (Eds.), The Performance of Public Enterprises Concepts and Measurements, Elsevier, pp. 247-263, 1984.

[12] Lovell, C.A.K. \& Eeckaut P. V., Frontier Tales: DEA and FDH, Mathematical Modeling in Economics, W.E. Diewert, K. Spremann, and F. Steling (ed.), Physica-Verlag, Berlin, pp. 446-457, 1993.

[13] Farrell M.J., The measurement of productive efficiency, Journal of the Royal Statistical Society A 120 pp. 253-281, 1957.

[14] Banker R.D., Charnes A. \& Cooper W.W., Some models for estimating technical and scale inefficiencies in data envelopment analysis, Management Science 30, pp. 1078-1092, 1984.

[15] Cooper W.W., Seiford L.M. \& Tone K., Data Envelopment Analysis, Kluwer Academic Publisher, Boston, USA, 2000.

[16] Charnes A., Clark C. T., Cooper, W. W. \& Golany, B., A Developmental Study of Data Envelopment Analysis in Measuring the Efficiency of Maintenance Units in the U.S. Air Forces, Annals of Operation Research, 2, pp. 95-112, 1985.

[17] Cullinane K. P. B. \& Wang T. Data Envelopment Analysis (DEA) and Improving Container Port Efficiency, in Brooks M.R. and Cullinane K.P.B. (eds) Port Governance and Performance, Research in Transportation Economics, Vol. 17, Elsevier: London, pp. 517-566, 2007. 
[18] Tavaresa G., A bibliography of data envelopment analysis (1978-2001), Rutcor Research Report, Rutgers University, Center for Operations Research, New Jersey, USA, 2002.

[19] Nozick, L. K., Borderas H. \& Meyburg A. H., Evaluation of travel demand measures and programs: A data envelopment analysis approach, Transportation Research Part A: Policy and Practice 32(5), pp 331-343, 1998.

[20] Odeck, J., Congestion, ownership, region of operation, and scale: Their impact on bus operator performance in Norway, Socio-Economic Planning Sciences 40, pp 52-69, 2006.

[21] Lupi M. \& Danesi A., Valutazione globale delle performance aeroportuali: applicazione della Data Envelopment Analysis (DEA) agli aeroporti italiani, in Linee guida per la programmazione dello sviluppo degli aeroporti regionali, Lupi M. (ed.), Franco Angeli, Milano, pp. 181-210, 2007.

[22] Russo F. \& Rindone C., Evaluation methods for evacuation planning, Proc. of Urban Transport XVI, Urban Transport and the Environment in the 21st century, Brebbia C. A. (ed.), WIT Press, Southampton, pp. 335-343, 2010.

[23] Russo, F. \& Rindone C., Data Envelopment Analysis (DEA) for evacuation planning. Proc. of Risk Analysis VII \& Brownfields V, Brebbia C. A. (ed.), WIT Press, Southampton, pp.455-467, 2010.

[24] Oum, TH., WG. Waters, \& C. Yu, A Survey of productivity and efficiency measurement in Rail transport, Journal of Transport Economics and Policy, 33, pp. 9-44, 1999.

[25] Graham D. J., Productivity and efficiency in urban railways: Parametric and non-parametric estimates, Transportation Research Part E 44 pp. 84-99, 2008.

[26] Cook W. D. \& Green, R. H., Project prioritization: a resource-constrained data envelopment analysis approach, Socio-Economic Planning Sciences, 34, pp. 85-99, 2000.

[27] Tsamboulas D. \& Mikroudis G., EFECT: evaluation framework of environmental impacts and costs of transport initiatives, Transportation Research Part D: transport and environment 5, pp. 283-303, 2000.

[28] Bernroider E.W.N. \& Stix V., Profile distance method: a multi-attribute decision making approach for information system investments. Decision Support Systems 42, pp 988- 998, 2006.

[29] Lahdelma R. \& Salminen P., Stochastic multicriteria acceptability analysis using the data envelopment model, European Journal of Operational Research 170, pp. 241-252, 2006.

[30] Wang T.-F., Song D.-W. \& Cullinane K., The Applicability of Data Envelopment Analysis to Efficiency Measurement of Container Ports, Proceedings of IAME Panama 2002 International Steering Committee, 13 15 November 2002, Panama, http:// www.eclac.cl/ Transporte/ perfil/ iame_papers/ papers.asp (last access July 2010), 2002.

[31] Wang T.-F., Cullinane K. \& Song D.-W., Container port production efficiency: A Comparative Study of DEA and FDH Approaches, Journal of 
the Eastern Asia Society for Transportation Studies, Vol.5, http://www.easts.info/2003journal/papers/0698.pdf, (last access, April 2011), 2003.

[32] Gonzalez M. M. \& Trujillo L., Reforms and infrastructure efficiency in Spain's container ports, Transportation Research Part A: Policy and Practice 42, pp 243-257, 2008.

[33] Russo F. \& Rindone C., Data Envelopment Analysis (DEA) nei porti container hub. I porti container italiani nel sistema Euro-Mediterraneo: dati di riferimento e stato dell'arte su modelli e metodi per l'analisi di domanda e offerta. F. Russo (ed), FrancoAngeli, Milan, 2010.

[34] Tongzon J., Efficiency measurement of selected Australian and other international ports using data envelopment analysis, Transportation Research Part A: Policy and Practice 35(2), pp 107-122, 2001.

[35] Valentine V. F. \& Gray R., The measurement of port efficiency using data envelopment analysis, Proceedings of the 9th world conference on transport research, Seoul, 22-27 July 2001.

[36] Cullinane K. P. B., Song, Ji P. \& Wang T., An Application of DEA Windows Analysis to Container Port Production Efficiency, Review of Network Economies, Vol.3, Issue 2, 2004.

[37] Cullinane K. P. B., Song D. \& Wang T., The Application of Mathematical Programming Approaches to Estimating Container Port Production Efficiency Journal of Productivity Analysis, 24, pp. 73-92, 2005.

[38] Cullinane K. P. B., Wang T., Song D. \& Ji P., The technical efficiency of container ports: Comparing data envelopment analysis and stochastic frontier analysis Transportation Research Part A: Policy and Practice 40, pp. 354-374, 2006.

[39] de Carvalho M. L. N. C., Performance Evaluation of the Portuguese Seaports: Evaluation in the European Context, Instituto Superior Técnico, Universidade Técnica de Lisboa, https:// dspace.ist.utl.pt /bitstream/2295/ 147760/1/ MLC (last access July 2010), 2007.

[40] Al-Eraqi A. S., Barros C. P., Mustaffa A. \& Khader A. T., Evaluating the Location Efficiency of Arabian and African Seaports Using Data Envelopment Analysis (DEA), WP 019/2007/DE/UECE, 2007.

[41] Ferrari C. \& Basta M., Price-cap e concessioni portuali: il caso dei terminal contenitori di Genova, Società Italiana degli Economisti dei Trasporti - IX Riunione Scientifica - Napoli, 2007

[42] Ferrari C. \& Basta M., Port concession fees based on the price-cap regulation: A DEA approach, Maritime Economics \& Logistics, 2009.

[43] Russo F. \& Musolino G., Container maritime transport at international scale: a procedure for aggregate estimation of demand variables. Proc. of Sustainable Development and Planning V, Brebbia C. A. (ed.), WIT Press, Southampton, Boston, 2011. ISBN 978-1-84564-544-1, 2011.

[44] Russo F. \& Assumma V., Container maritime transport at international scale: a model to simulate the demand flow in the Mediterranean basin. Proc. of Sustainable Development and Planning V, Brebbia C. A. (ed.), WIT Press, Southampton, Boston, 2011. ISBN 978-1-84564-544-1, 2011. 
[45] Russo F., Chilà G. \& Iannò D., Container maritime transport at international scale: a model choice of service and hub port. Proc. of Sustainable Development and Planning V, Brebbia C. A. (ed.), WIT Press, Southampton, Boston, 2011. ISBN 978-1-84564-544-1, 2011. 